\title{
Morphometric analysis in the shells of the planktonic foraminifera Orbulina universa: a source for paleoceanographic information?
}

\author{
Mónica Liliana Duque-Castaño ${ }^{1 *}$, Adriana Leonhardt ${ }^{1}$, María Alejandra Gómez Pivel ${ }^{2}$ \\ ${ }^{1}$ Universidade Federal do Rio Grande, Programa de Pós-Graduação em Oceanografia Física, Química e Geológica - Rio Grande - Rio \\ Grande do Sul - Brazil \\ (Av. Itália, km 8, Cx.P. 474, 96201-900, Rio Grande, RS, Brazil) \\ ${ }^{2}$ Universidade Federal do Rio Grande do Sul, Instituto de Geociências - Porto Alegre - Rio Grande do Sul - Brazil \\ (Av. Bento Gonçalves, 9500, Cx.P. 15001, 91501-970, Porto Alegre, RS, Brasil) \\ *Corresponding author: moliduque@gmail.com
}

\section{Abstract}

In this study, we describe morphometric analyses of Orbulina universa morphotypes presently found in the Western South Atlantic, and their relation to the upper water thermohaline indexes. We also investigate this relationship under glacial and interglacial conditions between 7.2 and $32 \mathrm{kyr}$ BP. Ten plankton samples distributed between $32^{\circ} 55^{\prime}$ and $26^{\circ} 20^{\prime} \mathrm{S}$ were selected for the analyses of modern O. universa specimens. Core SIS 188 was retrieved at $29^{\circ} 22^{\prime} \mathrm{S}, 47^{\circ} 28^{\prime} \mathrm{W}$ enabling the analysis of 21 fossil samples. Shell diameter, pore diameter, pore density and porosity were measured using SEM images. Chronology of core SIS188 is based on four AMS ${ }^{14} \mathrm{C}$ ages and the planktonic foraminifera oxygen isotope curve. Planktonic foraminifera relative abundances were converted into SST data using the Modern Analog Technique (MAT). Correlations between the morphometric parameters and temperature and salinity of surface Waters (modern samples) or paleotemperature (fossil samples) were calculated. Morphological characteristics of the analyzed shells allowed to differentiate two morphotypes of $O$. universa, namely Caribbean and Mediterranean in the studied region. For the Caribbean morphotype, the large pore density showed a negative correlation with both temperature and salinity. For the Mediterranean morphotype, no significant correlations were found. For fossil samples, no significant correlations were found between summer SST $(0-50 \mathrm{~m})$ and morphometric parameters for the Caribbean or the Mediterranean morphotypes. Possibly, other genotypes do exist in the fossil record, so modern and fossil morphotypes would not have the same behavior. Another explanation for the absence of correlation in fossil samples are errors associated with the SST estimates. Furthermore, fossil samples could represent distinct and more complex oceanographic conditions compared to current configuration, with Plata Plume Water and Brazil Malvinas Confluence migration playing a most significant role in the past.

Descriptors: Southwest Atlantic, Caribbean morphotype, Mediterranean morphotype, paleotemperature.

\section{INTRODUCTION}

Planktonic foraminifera have been widely used in paleoceanographic studies due to their global distribution, rapid evolution and great abundance. Since most species develop their life cycles in the upper $200 \mathrm{~m}$ of the ocean (Schiebel and Hemleben, 2017), they provide information about key paleoclimate variables such as paleo-sea surface temperature (SST) and salinity (SSS). For that purpose, census counts, coiling directions and the isotopic composition of shells have been frequently used as proxies

Submitted on: 29/January/2019

Approved on: 2/May/2019

http://dx.doi.org/10.1590/S1679-87592019025206701
(Emiliani, 1954; Imbrie and Kipp, 1971; Colombo and Cita, 1980; Hemleben et al., 1989). Also, planktonic foraminifera respond to changes in upper water properties modifying the size and density of shell pores (Bé, 1968; Seears, 2011; BouDagher-Fadel, 2012). Thus, the analysis of changes in the percentage, diameter and density of pores as well as the morphometry of the shells in some species may offer qualitative and quantitative data about past seawater properties (Bé, 1968; Bé et al., 1973; Frerichs et al., 1972; Li et al., 2009).

The use of planktonic foraminifera shell porosity as a paleoceanographic tool started in the 60's, when Bé (1968) first performed porosity measurements in 22 species from all latitudes and defined it according to latitude. Porosity is a 
parameter that combines information on the number of large and small pores and diameter of large and small pores in a given area. However, Quaternary studies have mainly focused in the usage of Orbulina universa, given that changes in SST, SSS and nutrient availability may be reflected in the morphometry of shells and pores of this species (Bé et al., 1973; Bé and Duplessy, 1976; Hecht et al., 1976; Spero, 1988; Lea et al., 2002; Schmidt et al., 2003).

Orbulina universa d'Orbigny occurs globally, with percentage representativity varying in the climatic belts. Usually is found in the tropical and subtropical regions, but it can also be found in polar waters due to the transport by surface currents (Schiebel and Hemleben, 2017). The first appearance of O. universa in the fossil record is defined approximately at 14.14 Ma (Lourens et al., 2004). This species is known for tolerating wide temperature and salinity ranges (Hemleben et al., 1989; Bijma et al., 1990) and develops its life cycle preferably in the photic zone. Its ontogenetic cycle includes four stages with different morphologies (Spero, 1988; Hemleben et al., 1989; Schiebel and Hemleben, 2017). In the adult phase, it forms a spherical chamber that encloses all previous chambers giving the species a spherical morphology that differs from all other planktonic forms. In this stage, the shell wall exhibits both small and large pores. While the large pores are used for the exchange of food and symbionts, the small ones are used for gas exchanges (Bé et al., 1980; Spero, 1988; Bijma et al., 1990).

Relationships between $O$. universa shell diameter and water temperature, as well as between the shell porosity and salinity and temperature have already been explored. This type of study has been performed in the Equatorial Indian Ocean and Western Pacific Ocean, focusing in changes in the porosities since the last glacial up to the Holocene, and showing that in low latitudes, lower porosities are correlated to higher salinities (Frerichs et al., 1972; Hecht et al., 1976; Li et al., 2009). On the other hand, porosity studies performed in North Atlantic mid latitudes have shown a correlation with SST (Colombo and Cita, 1980). However, none of these studies considered the existence of different morphotypes of $O$. universa.

De Vargas et al. (1999) reported three morphotypes of $O$. universa in the Atlantic Ocean based on genetic data. Morard et al. (2009) used biometric and genetic analyses to differentiate the Caribbean, Mediterranean and Sargasso morphotypes in the Southern Pacific, Southern Indian and Atlantic Oceans. Nevertheless, studies regarding porosities, pore density and shell size changes in $O$. univers $a$ in the Western South Atlantic - which could provide valuable information regarding Late Quaternary oceanographic conditions in this region - have not yet been performed.

The objective of this work is to understand the relationship between the upper water thermohaline indexes and the porosity and morphometric variation in shells of O. universa morphotypes found in the Western South Atlantic. We also investigate this relationship under glacial and interglacial conditions between 7.2 and $32 \mathrm{kyr}$ in the studied region.

\section{MATERIAL AND METHODS}

\section{STUDY AREA}

The south Brazilian continental margin is mostly influenced by the Brazil Current (BC), which flows southward in the offshore region transporting Tropical Water (TW) in the upper $200 \mathrm{~m}$ and South Atlantic Central Water (SACW) at the pycnocline layer. The TW (in which $O$. universa lives) is a warm $\left(>18^{\circ} \mathrm{C}\right)$ and saline ( $\left.>36\right)$ water mass (Silveira et al., 2000). The BC flows southwards until it meets the cold Malvinas Current forming the Brazil-Malvinas Convergence zone (BMC), at $38^{\circ} \mathrm{S}$. The BMC is an accentuated thermohaline front (Peterson and Stramma, 1991) and a zone of enhanced biological productivity.

In the south Brazilian continental shelf there is also the influence of the Plata Plume Water (PPW) (salinity: 32 ; temperature: $18^{\circ} \mathrm{C}$ - Pimenta et al., 2005). The influence of the Plata River $\left(35^{\circ} \mathrm{S}\right)$ extends along a coastal strip of $1300 \mathrm{~km}$. PPW reaches its northerly extreme at around of $25.2^{\circ} \mathrm{S}$ in August (austral winter) every year (Souza and Robinson, 2004). In contrast, during austral summer the plume is confined to river mouth. The seasonal variability of the river plume is controlled by the alongshore component of the wind stress (Piola et al., 2005).

Close to the studied piston core, the Santa Marta Cape $\left(29^{\circ} \mathrm{S}\right)$ is an important region at south Brazilian continental shelf because of the enhanced productivity of the waters in the region (Figure 1). The narrow continental shelf, the coastline orientation change and the wind influence seem to play a significant role in enhancing the offshore Ekman transport, leading to stronger upwelling south of the cape (Castelao and Barth, 2006). Shelf-break upwelling is also important and is a persistent process (Palma and Matano, 2009; Campos et al., 2013). Once on the shelf, SACW might be brought to the surface under upwelling favorable winds.

\section{ORBULINA UNIVERSA SAMPLES}

Ten zooplankton samples distributed along the southern Brazilian continental margin (between $32^{\circ} 55^{\prime}$ and $26^{\circ} 20^{\prime} \mathrm{S}$ ) 


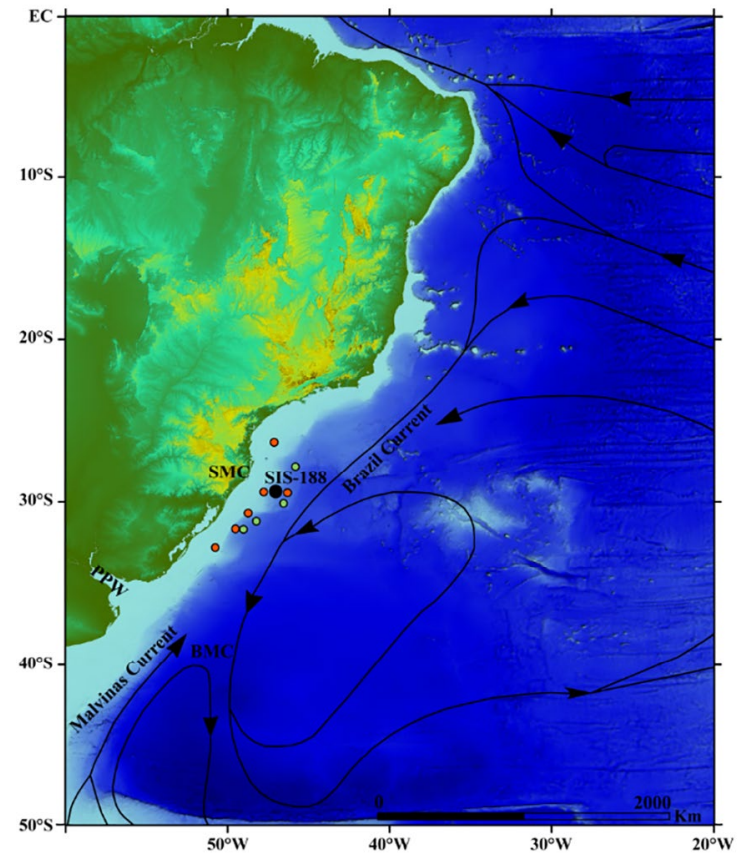

Figure 1. Location of the core SIS188 and the modern Orbulina universa samples. Orange dots correspond to the samples collected in spring; yellow dots correspond to the samples collected in autumn. Santa Marta Cape (SMC), Plata Plumer Water (PPW), Brazil Current (BC), Malvinas Current (MC) and Brazil-Malvinas Confluence (BMC) are also indicated in the map (based on Peterson and Stramma, 1991 and Piola et al., 2005).

were selected for the analyses of modern $O$. universa specimens (Table 1). Samples were retrieved in the spring of 2012 and in the autumn of 2015 by oblique hauls from $200 \mathrm{~m}$ depth to the water surface, using bongo nets with a $60 \mathrm{~cm}$ diameter mouth opening and $300 \mu \mathrm{m}$ mesh size. Samples were preserved in formaldehyde. Temperature and salinity data were obtained with a Seabird (SBE19) CTD device (Table 1).

Orbulina universa specimens were retrieved after wet-sieving through a $200 \mu \mathrm{m}$ mesh and picking using a Bogorov counting chamber. Altogether, 92 O. universa specimens were retrieved that were subsequently dried and imaged with a Scanning Electron Microscope (SEM).

Besides the zooplankton analyses, 21 samples from a late Quaternary sediment core were analyzed. Core SIS188 was retrieved by Fugro company at the southern Brazilian continental slope (2922'12'S, 47²8'38'W - Figure 1), at $1514 \mathrm{~m}$ water depth. The analyzed samples cover the upper $208.5 \mathrm{~cm}$ of the core, consisting mainly of calcareous mud, with smaller proportion of sandy mud and organic-matter rich layers.

The sampling used in this study does not present a regular spacing. Since the overall aim of this work is to evaluate the relationship between $O$. universa morphometric parameters and upper water thermohaline properties, the sampling focus was the representation of different paleoceanographic conditions instead of looking for high-resolution reconstruction. We distributed the samples through the core in order to cover a major time interval, possibly with different paleotemperatures. Downcore sample spacing is relatively high (up to $7 \mathrm{~cm}$ corresponding to up to $5 \mathrm{ka}$ ).

\section{MORPHOMETRIC ANALYSES AND RECOGNITION \\ OF ORBULINA UNIVERSA MORPHOTYPES}

Six to ten shells of $O$. universa (fossil and modern) (Figure 2) were imaged per sample with a Jeol, JSM 6610LV Scanning Electron Microscope (SEM), using a $140 \times 1000$ magnification. All specimens used for measurements were adults, with the spherical chamber enclosing the ones built in previous ontogenetic stages. Pore diameter, pore density and porosity were measured using the SEM images (Table 2 - modern samples and Table 3 fossil samples). The porosity was calculated according to Li et al. (2009):

Table 1. Distribution of modern Orbulina universa samples retrieved in spring 2012 and autumn 2015 at south Brazilian continental margin.

\begin{tabular}{|c|c|c|c|c|c|c|}
\hline \multicolumn{2}{|c|}{ Sampling location } & \multirow{2}{*}{ Sample ID } & \multirow{2}{*}{ Season } & \multirow{2}{*}{ Temperature $\left({ }^{\circ} \mathrm{C}\right) 0-50 \mathrm{~m}$} & \multirow{2}{*}{ Salinity $0-50 \mathrm{~m}$} & \multirow{2}{*}{$\begin{array}{l}\text { Number of } O \text {. universa } \\
\text { specimens per sample }\end{array}$} \\
\hline Latitude & Longitude & & & & & \\
\hline $32^{\circ} 55.370^{\prime} \mathrm{S}$ & $50^{\circ} 17.770^{\prime} \mathrm{W}$ & P5-11 & Spring & 19 & 34.2 & 8 \\
\hline $31^{\circ} 42.371^{\prime} \mathrm{S}$ & $48^{\circ} 59.446^{\prime} \mathrm{W}$ & P9-3A & Autumn & 22.9 & 36.4 & 9 \\
\hline $31^{\circ} 39.238^{\prime} \mathrm{S}$ & $49^{\circ} 29.745^{\prime} \mathrm{W}$ & P5-18 & Spring & 18 & 34.5 & 10 \\
\hline $31^{\circ} 12.744^{\prime} \mathrm{S}$ & $48^{\circ} 56.648^{\prime} \mathrm{W}$ & P9-22 & Autumn & 23 & 36.8 & 6 \\
\hline $30^{\circ} 42.910^{\prime} \mathrm{S}$ & $48^{\circ} 48.866^{\prime} \mathrm{W}$ & P5-23 & Spring & 22 & 34.8 & 9 \\
\hline $30^{\circ} 07.49^{\prime} \mathrm{S}$ & $47^{\circ} 08.760^{\prime} \mathrm{W}$ & P9-4A & Autumn & 22.5 & 36.4 & 10 \\
\hline $29^{\circ} 25.583^{\prime} \mathrm{S}$ & $47^{\circ} 44.953^{\prime} \mathrm{W}$ & P5-29 & Spring & 21.3 & 34.4 & 10 \\
\hline $29^{\circ} 22.780^{\prime} \mathrm{S}$ & $47^{\circ} 07.532^{\prime} \mathrm{W}$ & P5-30 & Spring & 19.7 & 33.5 & 10 \\
\hline $27^{\circ} 50.490^{\prime} \mathrm{S}$ & $45^{\circ} 7.544^{\prime} \mathrm{W}$ & P9-5A & Autumn & 23.8 & 37 & 8 \\
\hline $26^{\circ} 20.64^{\prime} \mathrm{S}$ & $46^{\circ} 66.707^{\prime} \mathrm{W}$ & P5-41 & Spring & 21.8 & 36.1 & 10 \\
\hline
\end{tabular}



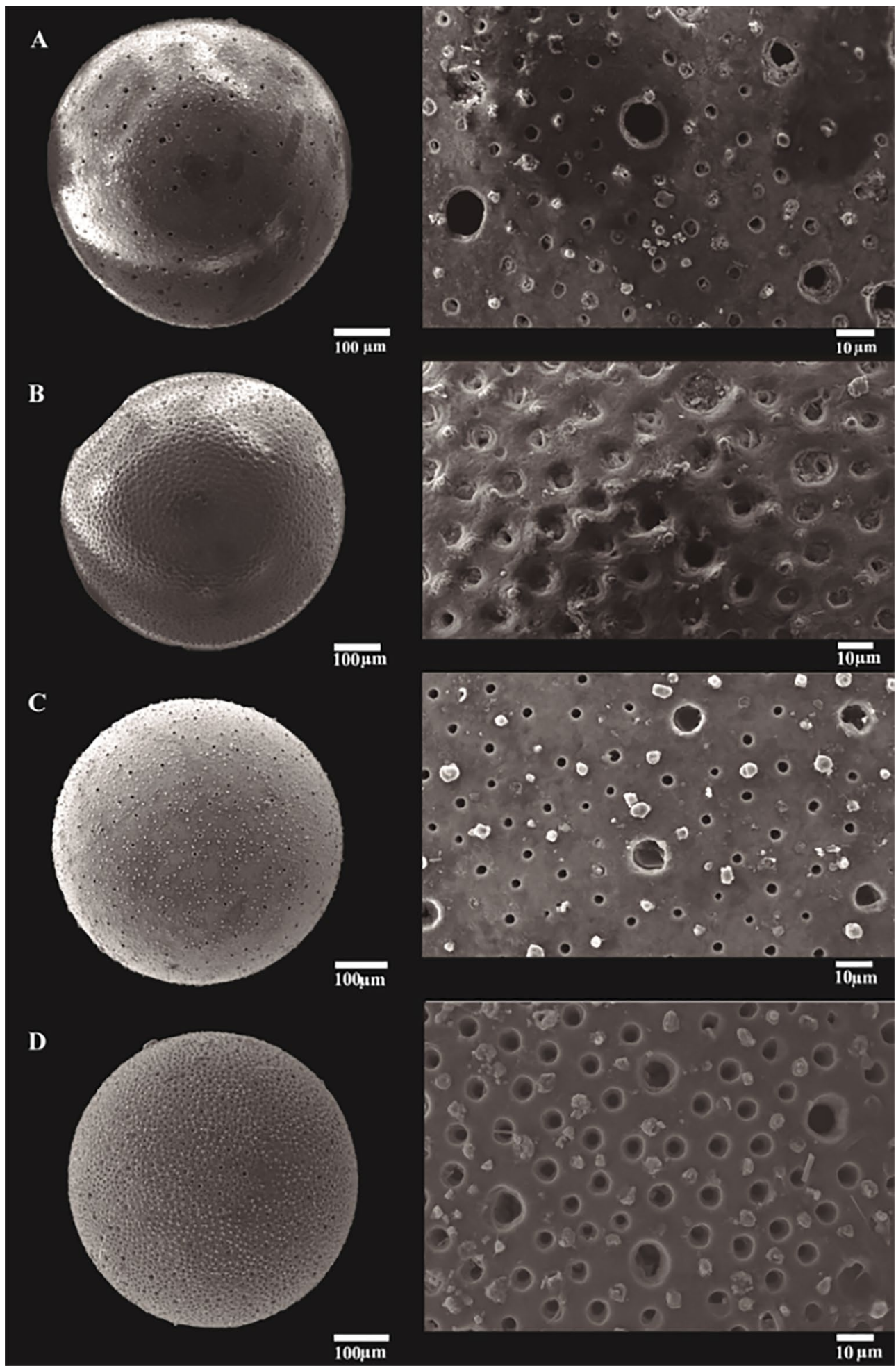

Figure 2. Orbulina universa morphotypes. A. Mediterranean morphotype from core SIS188; B. Caribbean morphotype from core SIS188; C. Mediterranean morphotype from modern samples; D. Caribbean morphotype from modern samples. 
Table 2. Morphometric characteristics of modern Orbulina universa samples retrieved at south Brazilian continental margin.

\begin{tabular}{|c|c|c|c|c|c|c|c|c|c|c|}
\hline \multirow[b]{2}{*}{$\begin{array}{l}\text { Samples } \\
\text { ID }\end{array}$} & \multicolumn{5}{|c|}{ Caribbean morphotype } & \multicolumn{5}{|c|}{ Mediterranean morphotype } \\
\hline & Specimens & $\begin{array}{c}\text { Porosity } \\
(\%)\end{array}$ & Diameter & $\begin{array}{l}\text { large pore } \\
\text { density } \\
\left(/ 110 \mu \mathrm{m}^{2}\right)\end{array}$ & $\begin{array}{c}\text { small } \\
\text { pore } \\
\text { density } \\
\left(/ 110 \mu \mathrm{m}^{2}\right)\end{array}$ & Specimens & $\begin{array}{c}\text { Porosity } \\
(\%)\end{array}$ & Diameter & $\begin{array}{l}\text { large pore } \\
\text { density } \\
\left(/ 110 \mu \mathrm{m}^{2}\right)\end{array}$ & $\begin{array}{c}\text { small pore } \\
\text { density } \\
\left(/ 110 \mu \mathrm{m}^{2}\right)\end{array}$ \\
\hline P5-11 & 5 & 15.2 & 564.521 & 19 & 32 & 3 & 4 & 651.050 & 5 & 50 \\
\hline P9-3A & 3 & 14.1 & 558.819 & 6 & 47 & 6 & 9.9 & 517.712 & 5 & 54 \\
\hline P5-18 & 3 & 15.1 & 637.171 & 17 & 45 & 7 & 10.1 & 684.988 & 10 & 54 \\
\hline P9-22 & 1 & 14.6 & 601.234 & 8 & 16 & 5 & 6.5 & 618.423 & 4 & 45 \\
\hline P5-23 & 8 & 11.3 & 533.036 & 13 & 20 & 1 & 11 & 452.548 & 6 & 38 \\
\hline P9-4A & 4 & 12.8 & 561.547 & 14 & 26 & 6 & 6.9 & 695.783 & 5 & 48 \\
\hline P5-29 & 3 & 14.8 & 635.854 & 11 & 34 & 7 & 6.4 & 584.170 & 4 & 56 \\
\hline P5-30 & 6 & 16.1 & 646.431 & 16 & 23 & 3 & 7.3 & 591.517 & 6 & 46 \\
\hline P9-5A & 5 & 11.5 & 606.277 & 5 & 39 & 3 & 7.3 & 625.213 & 5 & 57 \\
\hline P5-41 & 9 & 16.3 & 607.669 & 16 & 40 & 1 & 9.1 & 601.741 & 4 & 54 \\
\hline
\end{tabular}

Table 3. Morphometric characteristics of fossil Orbulina universa samples retrieved at core SIS 188.

\begin{tabular}{|c|c|c|c|c|c|c|c|c|c|c|c|c|}
\hline \multirow[b]{2}{*}{$\begin{array}{l}\text { Depth } \\
(\mathrm{cm})\end{array}$} & \multirow[b]{2}{*}{$\begin{array}{l}\text { O. universa } \\
\text { specimens } \\
\text { per sample }\end{array}$} & \multirow[b]{2}{*}{$\begin{array}{c}\text { Age } \\
(\mathrm{ka} \mathrm{AP})\end{array}$} & \multicolumn{5}{|c|}{ Caribbean morphotype } & \multicolumn{5}{|c|}{ Mediterranean morphotype } \\
\hline & & & Specimens & $\begin{array}{c}\text { Porosity } \\
(\%)\end{array}$ & Diameter & $\begin{array}{l}\text { large pore } \\
\text { density } \\
\left(/ 110 \mu \mathrm{m}^{2}\right)\end{array}$ & $\begin{array}{c}\text { small pore } \\
\text { density } \\
\left(/ 110 \mu \mathrm{m}^{2}\right)\end{array}$ & Specimens & $\begin{array}{c}\text { Porosity } \\
(\%)\end{array}$ & Diameter & $\begin{array}{l}\text { large pore } \\
\text { density } \\
\left(/ 110 \mu \mathrm{m}^{2}\right)\end{array}$ & $\begin{array}{c}\text { small pore } \\
\text { density } \\
\left(/ 110 \mu \mathrm{m}^{2}\right)\end{array}$ \\
\hline 23 & 10 & 7.42 & 4 & 18.0 & 552.983 & 29 & 9 & 6 & 9.0 & 487.955 & 10 & 37 \\
\hline 30 & 8 & 8.18 & 4 & 17.0 & 583.381 & 12 & 29 & 4 & 9.7 & 506.426 & 6 & 27 \\
\hline 35 & 10 & 8.73 & 4 & 18.8 & 558.466 & 8 & 36 & 6 & 10.4 & 597.974 & 6 & 33 \\
\hline 42 & 10 & 9.50 & 4 & 14.9 & 521.453 & 5 & 39 & 6 & 11.7 & 539.110 & 3 & 42 \\
\hline 47 & 8 & 10.04 & 3 & 12.9 & 451.774 & 11 & 24 & 5 & 8.4 & 553.651 & 9 & 26 \\
\hline 54 & 9 & 10.81 & 5 & 17.5 & 498.706 & 22 & 12 & 4 & 12 & 505.086 & 5 & 42 \\
\hline 59 & 9 & 14.43 & 8 & 14.0 & 520.980 & 5 & 43 & 1 & 8.4 & 458.094 & 5 & 46 \\
\hline 66 & 7 & 19.50 & 4 & 15.4 & 462.322 & 7 & 34 & 3 & 4.8 & 375.105 & 3 & 27 \\
\hline 70.5 & 10 & 20.04 & 3 & 18.4 & 488.329 & 7 & 34 & 7 & 9.6 & 493.925 & 4 & 30 \\
\hline 78 & 9 & 20.95 & 4 & 22.0 & 603.319 & 11 & 31 & 5 & 10 & 513.066 & 4 & 35 \\
\hline 82.5 & 10 & 21.49 & 6 & 16.8 & 609.737 & 6 & 32 & 4 & 16.7 & 474.809 & 6 & 46 \\
\hline 90 & 8 & 22.40 & 4 & 19.0 & 566.972 & 7 & 38 & 4 & 9.7 & 552.261 & 4 & 37 \\
\hline 94 & 10 & 22.85 & 5 & 19.0 & 562.573 & 9 & 33 & 5 & 9.5 & 506.201 & 4 & 49 \\
\hline 101.5 & 10 & 23.79 & 0 & - & - & - & - & 10 & 6.1 & 504.739 & 3 & 22 \\
\hline 106.5 & 10 & 34.39 & 6 & 19.2 & 561.333 & 7 & 29 & 4 & 5.7 & 629.956 & 4 & 23 \\
\hline 113.5 & 10 & 25.24 & 4 & 13.9 & 478.317 & 4 & 40 & 6 & 6.8 & 439.864 & 3 & 41 \\
\hline 118 & 10 & 25.56 & 6 & 17.1 & 454.519 & 9 & 40 & 4 & 8.8 & 442.897 & 4 & 35 \\
\hline 125.5 & 8 & 26.11 & 3 & 21.1 & 405.924 & 11 & 32 & 5 & 10.7 & 543.982 & 6 & 27 \\
\hline 130 & 10 & 26.43 & 5 & 16.6 & 483.924 & 5 & 49 & 5 & 9.6 & 438.715 & 2 & 46 \\
\hline 137.5 & 9 & 26.98 & 5 & 19.3 & 523.650 & 9 & 48 & 4 & 9.7 & 495.444 & 4 & 18 \\
\hline 185 & 9 & 30.42 & 6 & 16.4 & 525.478 & 8 & 39 & 4 & 9.6 & 543.059 & 3 & 36 \\
\hline 197 & 9 & 31.29 & 7 & 18.8 & 520.484 & 7 & 43 & 2 & 9.9 & 478.018 & 4 & 45 \\
\hline 208.5 & 6 & 32.12 & 5 & 9.5 & 463.767 & 2 & 40 & 1 & 6.8 & 607.637 & 3 & 37 \\
\hline
\end{tabular}

$$
\left[\mathrm{N} \times \pi \times(\mathrm{D} / 2)^{2}+\mathrm{n} \times \pi(\mathrm{d} / 2)^{2}\right] / 1 \times \mathrm{W}
$$

where $\mathrm{N}=$ number of large pores $(10-19 \mu \mathrm{m})$; $\mathrm{n}=$ number of small pores $(1-9 \mu \mathrm{m}) ; \mathrm{D}=$ large pores diameter; $d=$ small pores diameter; $1=$ length of the analyzed area $\mathrm{e} \mathrm{w}=$ width of the analyzed area.

No recrystallized shells were measured in this study. Porosity and pore density were measured on the external surface of the shell, according to studies like Li et al. (2009). On the other hand, Morard et al. (2009) and Marshall et al. (2015) performed the measurements on the internal surface of the shell, after breaking it. In our measurements, only the shell central area was analyzed, avoiding image distortions and possible errors related to its curvature. Thereby, we avoid Orbulina shells destruction, which may be used for other paleoceanographic studies. 
Morphotypes were distinguished based on morphological criteria described by Morard et al. (2009). Caribbean morphotype exhibits high porosity (13-22\%) and its pores have uniform sizes. Mediterranean morphotype exhibits low porosity (4-12\%) and possess two distinctive size of pores.

\section{CORE SIS188 AGE MODEL}

Chronology is based on the correlation of planktonic foraminifera oxygen isotope curve of SIS188 core with the isotopic curve of Lisiecki and Stern (2016), using four AMS ${ }^{14} \mathrm{C}$ dating as control points. The age model was built using Analyseries 2.0 software (Paillard et al., 1996). Oxygen isotope analysis and ${ }^{14} \mathrm{C}$ dating were performed using Globigerinoides ruber (white) tests $(>150 \mu \mathrm{m})$. Ages obtained by ${ }^{14} \mathrm{C}$ dating were corrected for reservoir effect using the Marine Reservoir Correction Database ((Delta $\mathrm{R}=54.0+/-42.0$ based on ages from De Masi (1999), Angulo et al. (2005), and Alves et al. (2015) and converted to calibrated ages (Table 4) according to the calibration curve Marine13 (Reimer et al., 2013). Dating analysis were made at the Radiocarbon Laboratory of the Universidade Federal Fluminense (LACUFF) and isotopic analysis were performed at Mass Spectrometry Laboratory of California University.

\section{Paleotemperature estimates}

Planktonic foraminifera relative abundances were converted into SST data using the Modern Analog Technique (MAT) (Hutson, 1980). In order to do that, at least 300 specimens were identified by sample $(>150 \mu \mathrm{m}$ size fraction) (CLIMAP, 1976). The calibration dataset ForCenS2017 (Siccha and Kucera, 2017) was utilized to extract the modern faunal composition data for the South Atlantic and part of Equatorial Atlantic $\left(55^{\circ} \mathrm{S}-\right.$ $6^{\circ} \mathrm{N} ;-62^{\circ} \mathrm{W}-22 \mathrm{~W}^{\circ}$ ). Furthermore, austral summer, winter and mean annual temperatures were obtained from the World Ocean Atlas (WOA13, Locarnini et al., 2013) for each location of the calibration database. The depth ranges of $0-50 \mathrm{~m}, 0-75 \mathrm{~m}$ and $50-100 \mathrm{~m}$ were considered. Finally, the data were treated in the software Past, Modern Analog Technique tool.

Only the SST was estimated. The SSS estimates contain considerable noise, preventing the use of its absolute values for testing correlations.

Table 4. Radiocarbon ages for core SIS188.
RELATIONSHIP BETWEEN MORPHOMETRIC

\section{PARAMETERS AND THERMOHALINE INDEXES}

For modern samples, correlations between morphometric parameters (shell diameter, porosity, large pores density, small pores density) and sea surface temperature and salinity (considering the mean for the range depths $0-50 \mathrm{~m}$, $0-75 \mathrm{~m}$ and $50-100 \mathrm{~m}$ ) were calculated. Significance of correlations were evaluated by bootstrapping, with 5,000 iterations, $\alpha=0.05$. The analyses were performed using the statistical software MULTIV (Pillar, 2006).

The same statistical treatment was applied to the fossil samples, except considering only paleotemperature as the environmental variable.

\section{RESULTS}

Morphological characteristics of the analyzed shells allowed to differentiate two morphotypes of O. universa in the studied region, namely Caribbean and Mediterranean (Figure 2).

\section{ORBULINA UNIVERSA ANALYSIS: MODERN SAMPLES}

The diameter of the Caribbean morphotype ranged between $557.7 \mu \mathrm{m}$ and $648.5 \mu \mathrm{m}$. The minimum and maximum porosity were respectively $11.3 \%$ and $16.7 \%$. Pore density varied between 5 and 19 for large pores and 20 and 47 for small pores (both densities calculated for an $110 \mu \mathrm{m}^{2}$ surface area) (Table 2).

The Mediterranean morphotype showed a diameter range between $451.3 \mu \mathrm{m}$ and $690.2 \mu \mathrm{m}$. The minimum porosity was $4 \%$ and the maximum $10.6 \%$. The large pore density varied between 4 and 10 (in an area of $110 \mu \mathrm{m}^{2}$ ) and the small pore density between 38 and 57 (for the same area) (Table 2).

For the Caribbean morphotype, the large pore density showed a negative correlation with both temperature $(\mathrm{r}=-$ $0.83 ; p=0.01)$ and salinity $(\mathrm{r}=-0.7 ; p=0.03)$ for the depth range $0-50 \mathrm{~m}$ (Figure 3 ). The same pattern was found for $0-75 \mathrm{~m}$ (temperature: $\mathrm{r}=-0.82, p=0.01$; salinity: $\mathrm{r}=-0.72$, $p=0.02$ ), but not for $50-100 \mathrm{~m}$ water depth, where no significant correlation was found. The correlations between the remaining morphometric parameters with temperature and salinity were not found significant for any depth range.

For the Mediterranean morphotype, none correlation was found to be significant for 0-50 m (Figure 4), 0-75 m or $50-100 \mathrm{~m}$ depth ranges.

\begin{tabular}{lcccc}
\hline Sample depth $(\mathrm{cm})$ & ${ }^{14} \mathrm{C}$ Age & Error (years) & Calibrated age & Lab (LACUFF) Code \\
\hline 21 & 6725 & 31 & 7204 & 170210 \\
54 & 9921 & 34 & 10812 & 170055 \\
113.5 & 21360 & 59 & 25243 & 170056 \\
180.5 & 26325 & 77 & 30099 & 170211 \\
\hline
\end{tabular}



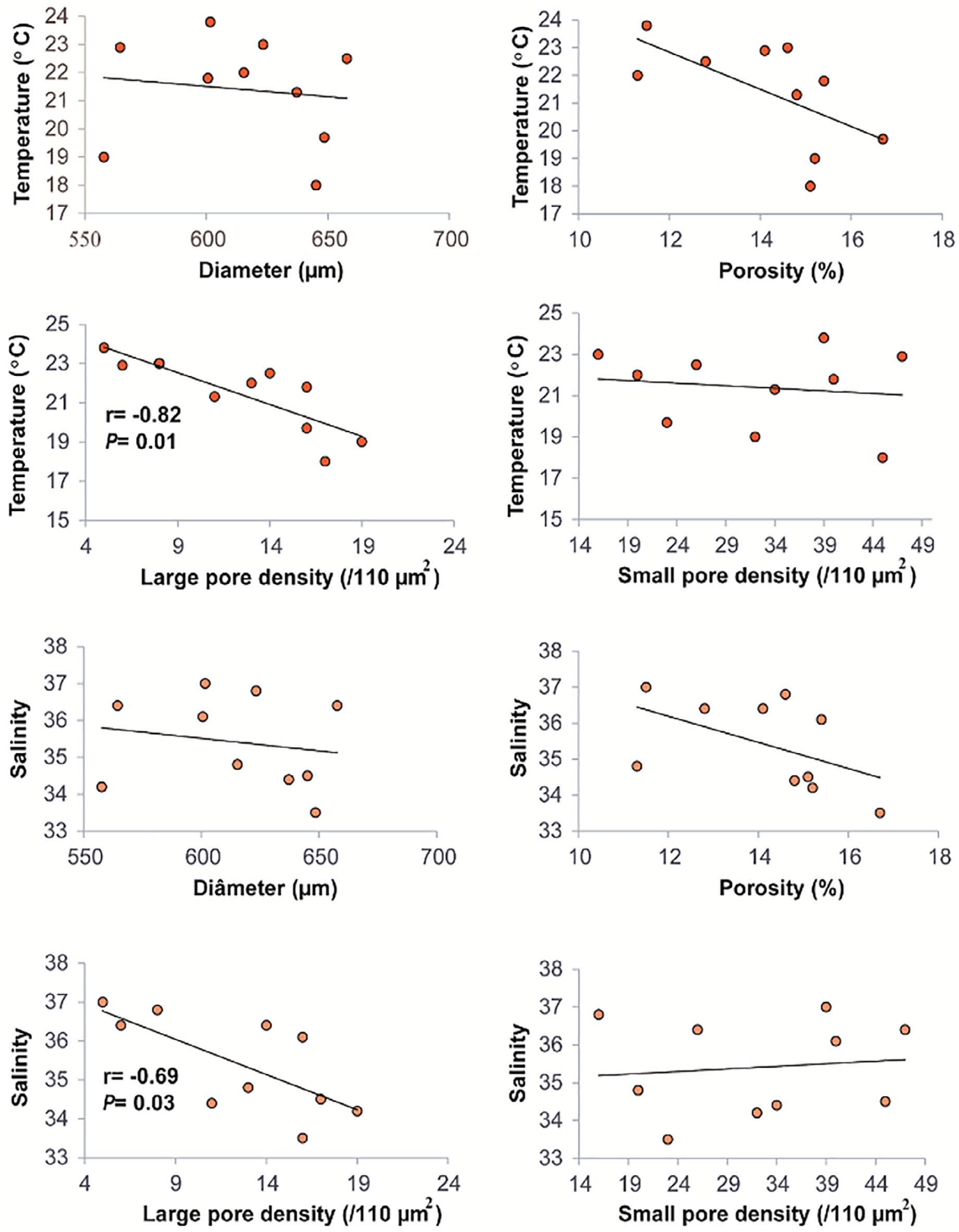

Figure 3. Correlation coefficients between temperature and salinity (0-50m water depth) and morphometric variables of modern Caribbean morphotype samples. 

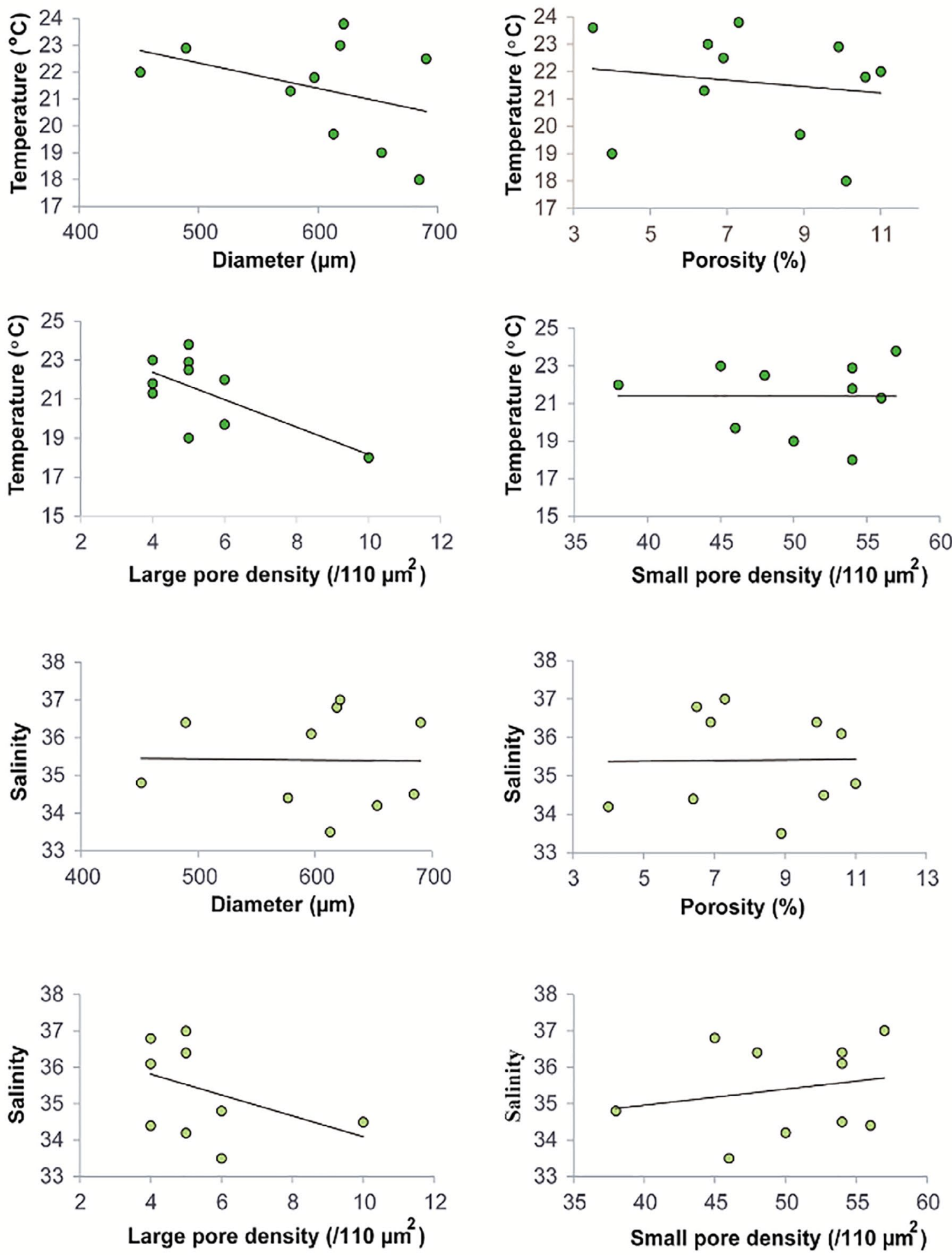

Figure 4. Correlation coefficients between temperature and salinity $(0-50 \mathrm{~m}$ water depth) with morphometric variables of modern Mediterranean morphotype samples. 


\section{CHRONOLOGY AND SEDIMENTATION RATES FOR}

\section{CORE SIS 188}

Radiocarbon datings (Table 4) along with the Globigerinoides ruber isotope curve (Figure 5) allowed to build the age model for core SIS188 and to calculate changes in sedimentation rates for the last $32 \mathrm{kyr}$ (Figure 6). Between 32 and $25.2 \mathrm{kyr}$ BP, sedimentation rates were had been highest for the studied section, reaching $13.8 \mathrm{~cm} / \mathrm{ka}$. Between 24.4 and 19.5 kyr BP sedimentation rates decreased to $8.3 \mathrm{~cm} / \mathrm{ka}$ and from 14.4 to $10.8 \mathrm{kyr} \mathrm{BP}$, the lowest sedimentation rates are recorded, reaching $1.4 \mathrm{~cm} / \mathrm{ka}$. Finally, from $10 \mathrm{kyr}$ BP onward sedimentation rate increases again to $9.1 \mathrm{~cm} / \mathrm{ka}$.

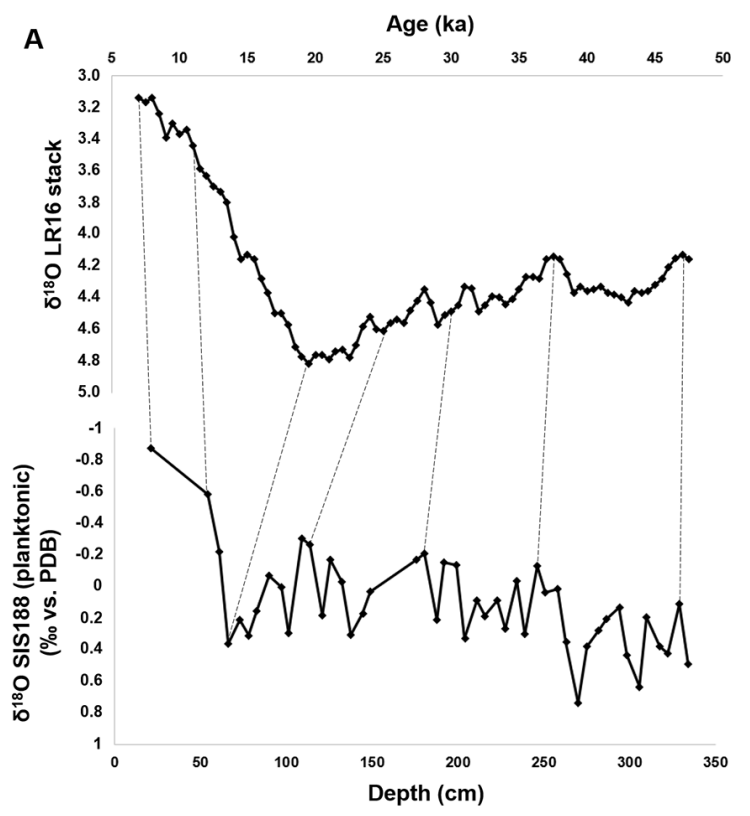

B

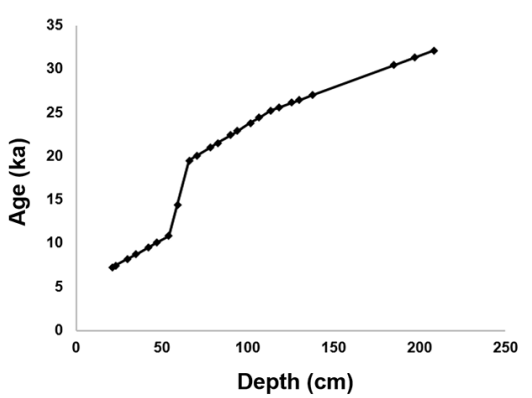

Figure 5. A. Reference curve Lisiecki and Stern (2016) (upper graph) and age model of core SIS118 (lower graph). B. Age-depth model based on Analyseries 2.0 (Paillard et al., 1996) for the upper part of core SIS118.

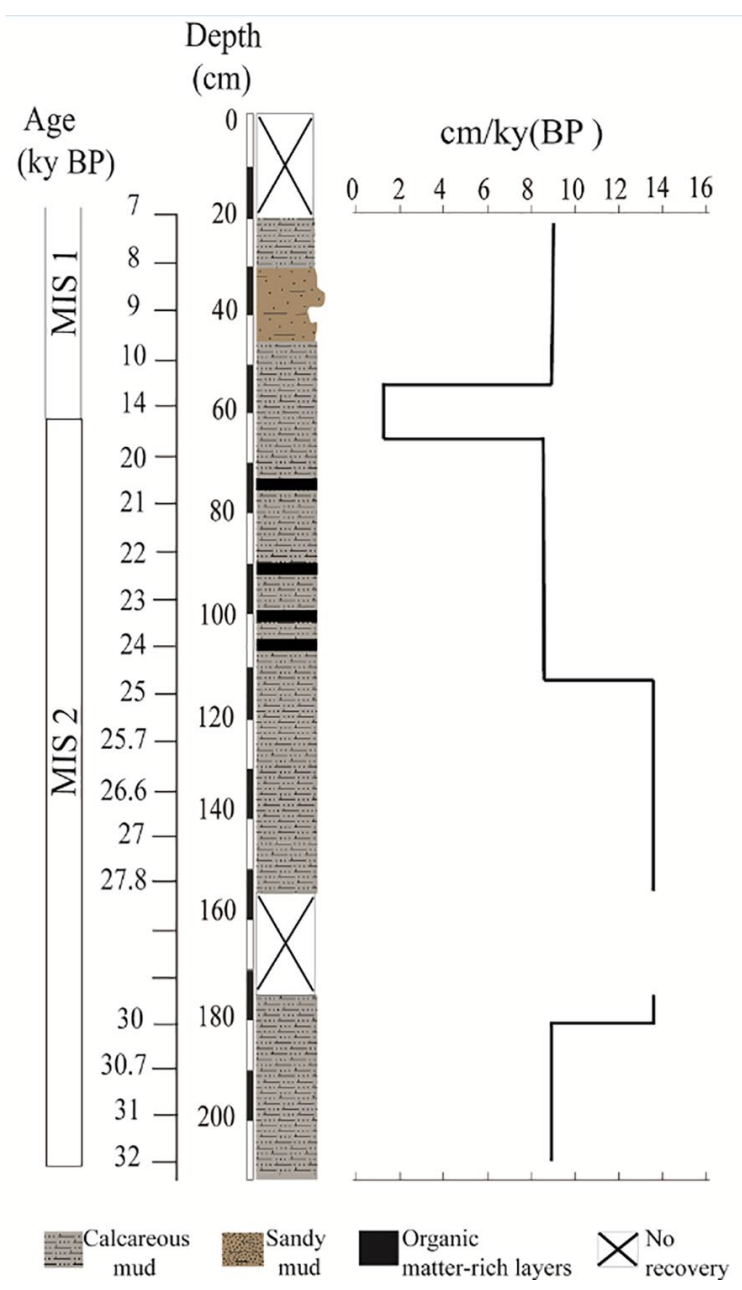

Figure 6. Core description and estimated sedimentation rates for core SIS188.

\section{ORBULINA UNIVERSA MORPHOMETRIC ANALYSES ALONG SIS188 CORE - CARIBBEAN MORPHOTYPE}

The diameter of the Caribbean morphotype in the fossil samples ranged between $409 \mu \mathrm{m}$ and $609 \mu \mathrm{m}$. Highest values were found for samples between 32 and $21.5 \mathrm{kyr}$ BP and lowest values for samples between 19.5 and $7.4 \mathrm{kyr}$ $\mathrm{BP}$, although with a slight increase in diameter at $8.5 \mathrm{kyr}$ BP (Figure 7a).

Minimum porosity was $13 \%$ and maximum $22 \%$. Values were highest between 32 and $22.44 \mathrm{kyr}$ BP and lowest between 21.5 and 14.4 kyr BP. Afterwards, between 8.7 and 7.4 kyr BP porosity become high again (Figure $7 b$ ).

Large and small pore densities showed opposite patterns. Large pores (Figure 7c) presented lowest density values during MIS 2 and peaks during MIS 1. Meanwhile, small pore 

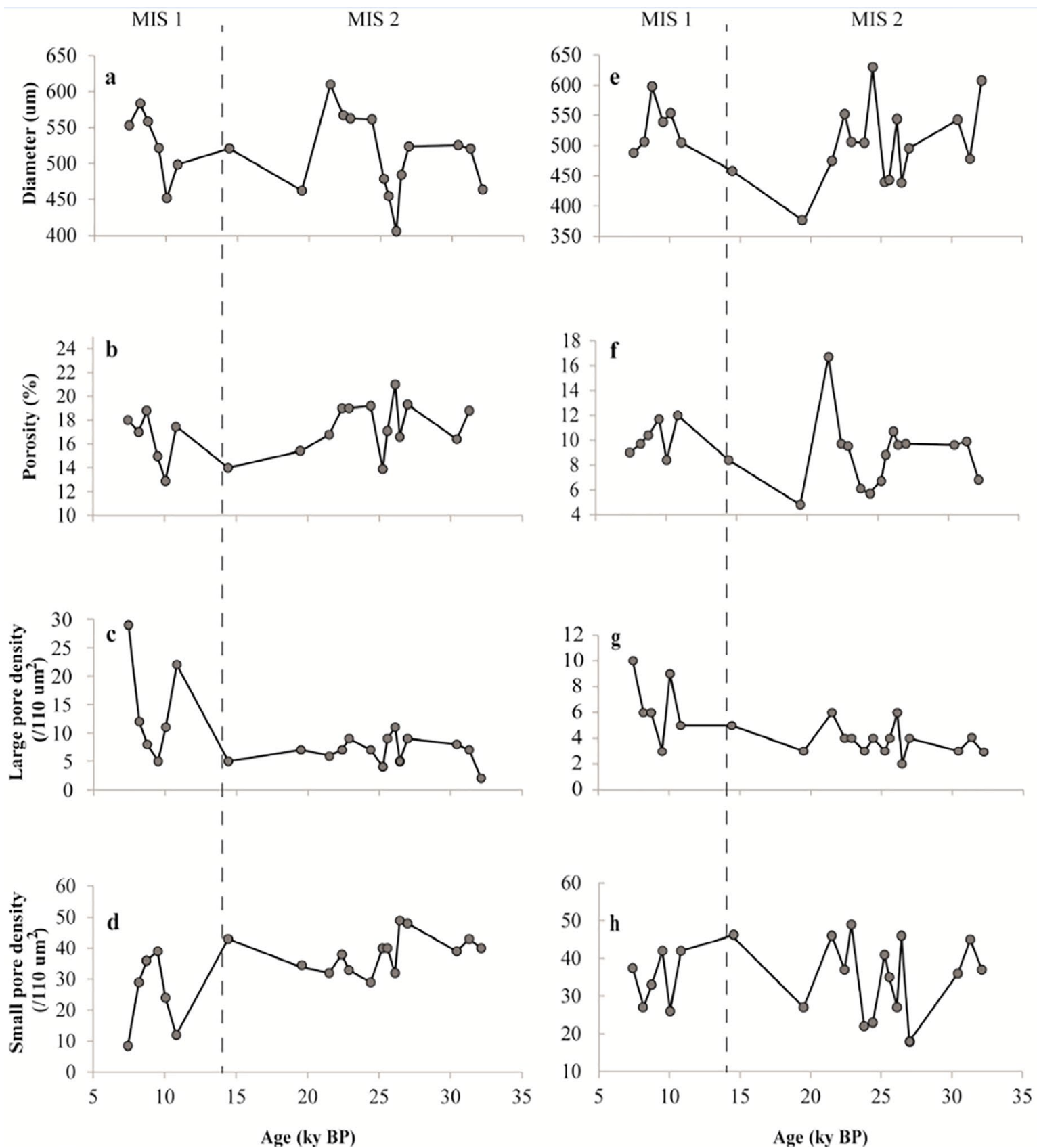

Figure 7. Downcore morphometric changes observed in Orbulina universa Caribbean morphotype (left) and Mediterranean morphotype (right) for core SIS188.

densities (Figure 7d) presented high values during MIS 2, and lower values during MIS 1.

\section{ORBULINA UNIVERSA MORPHOMETRIC ANALYSES} ALONG SIS188 CORE - MEDITERRANEAN MORPHOTYPE

Changes in the diameter of specimens from the Mediterranean morphotype are more pronounced than those observed in the Caribbean morphotype. The minimum diameter found was of $375 \mu \mathrm{m}$ and the largest was of $629 \mu \mathrm{m}$. The interval between 31.2 and $22.4 \mathrm{kyr}$ BP shows the major variations of diameter along the studied section. Upward in the section, the diameter presents a size decreasing trend up to $14.4 \mathrm{kyr}$ BP. Between 10.8 and $7.4 \mathrm{kyr}$ BP, the diameter values remain high (Figure 7e).

Porosity (Figure 7f) showed lower values than those from the Caribbean morphotype. Values oscillated between 4 and $16.7 \%$. The curve shows large oscillations during MIS 2 with 
a maximum peak at $21.5 \mathrm{kyr} \mathrm{BP}$ and a minimum at $19.5 \mathrm{kyr}$ BP. During MIS1, values remain more stable.

Large pore densities in the Mediterranean morphotype ranged between 4 and 9 large pores in a $110 \mu \mathrm{m}^{2}$ area). Generally, values were lower during MIS 2 and higher during MIS1 (Figure 7g).

Different from the Caribbean morphotype, small pore densities in the Mediterranean morphotype (Figure 7h) did not present an inverse pattern with large pore densities. This parameter exhibits large fluctuations along the whole studied interval.

\section{Changes IN PLANKTONIC FORAMINIFERA FAUNA} ALONG CORE SIS188

Twenty-six planktonic foraminifera species were recognized in the analyzed samples. The most contrasting faunal changes were found at the transition between MIS2 and MIS1 (14 kyr BP). Typically, cold and nutrient-rich water species such as Turborotalita quinqueloba, Neogloboquadrina pachyderma and left-coiling Globorotalia truncatulinoides were more abundant during the glacial period (MIS2). On the other hand, warm-water species such as $O$. universa, Globigerinoides ruber (white and pink), Trilobatus sacculifer (with or without sac-like chamber) and Globigerinella calida became more abundant during MIS1, most of them specially during the Holocene, since 8.7 kyr BP (Figure 8).

\section{DOWNCORE PALEO-SST RECONSTRUCTION AND} CORRELATION WITH FOSSIL ORBULINA UNIVERSA SAMPLES

Summer, winter and mean annual SSTs for each analyzed sample are plotted in Figure 9, representing mean values for the $0-50 \mathrm{~m}$ water depth. This depth range was the one that yielded the highest correlation between the modern temperature obtained by the CTD device and the reconstructed paleotemperatures of the calibration dataset. Therefore, we consider only these results to evaluate the correlation between paleotemperatures and the morphometric parameters of $O$. universa.

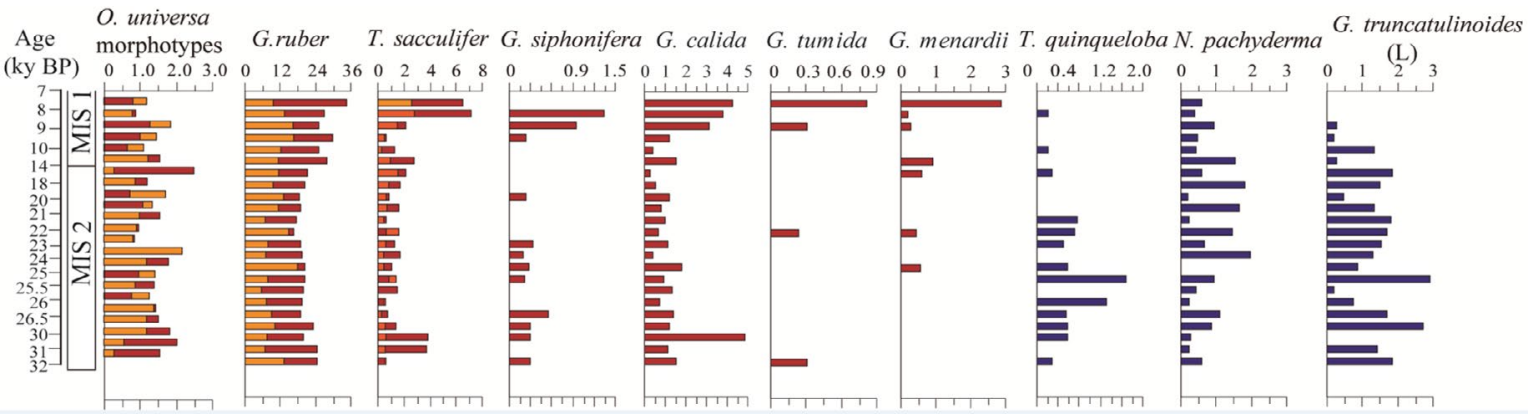

Figure 8. Relative abundances (\%) of warm-water species (in red) versus cold-water species (in blue) along core SIS188. In the Orbulina universa plot, the red bars correspond to the Caribbean morphotype and the yellow ones to the Mediterranean morphotype. In the Globigerinodes ruber plot, the red bars correspond to the white morphotype and the yellow ones to the pink morphotype. For T. sacculifer, the yellow and red bars respectively indicate specimens with and without the sac-like chamber.

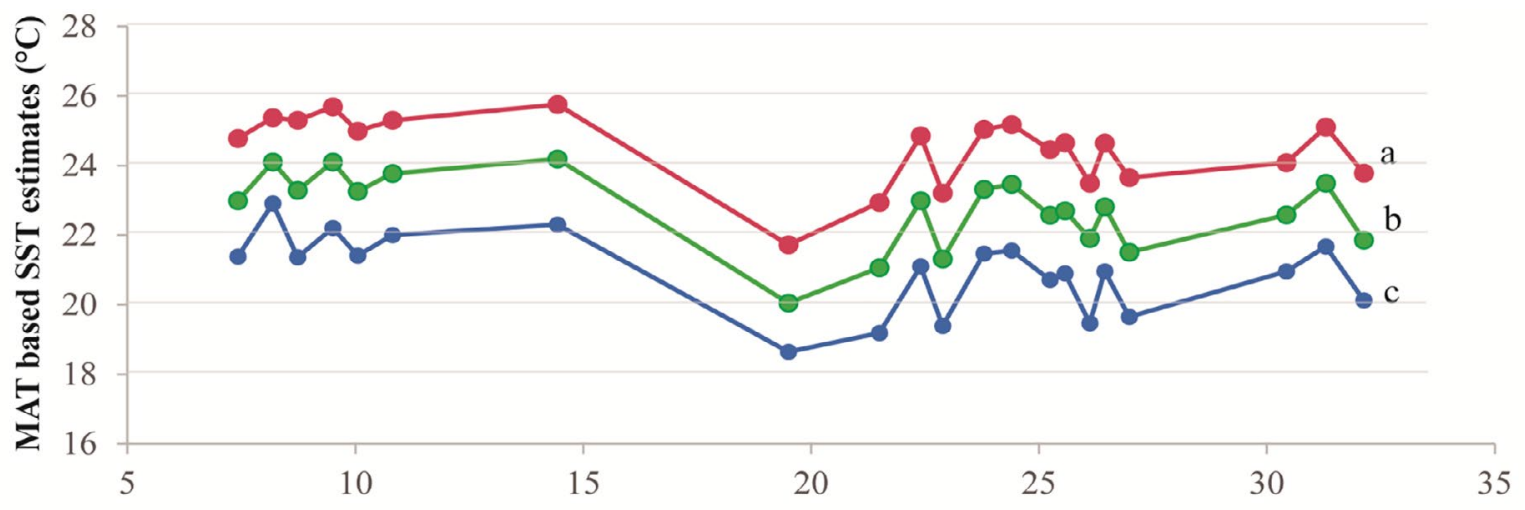

Age (ky BP)

Figure 9. Paleo-SST estimates $\left({ }^{\circ} \mathrm{C}\right)$ for the upper $50 \mathrm{~m}$ water depth according to SIS188 record: (a) summer SST, (b) mean annual SST and (c) winter SST. 
Between 32.1 and $22.4 \mathrm{kyr}$ BP SST estimates show only minor fluctuations, keeping pretty much constant values. Mean summer SST during this interval is $24.3^{\circ} \mathrm{C}$. From then on, temperatures drop, reaching a minimum value at $19.5 \mathrm{kyr} \mathrm{BP}\left(21.7^{\circ} \mathrm{C}\right)$, during the LGM. Since 14.4 kyr BP (close to the transition between MIS2 and MIS1), temperatures rise again and stay high during the Holocene. Mean summer SST through during the Holocene is $25.3^{\circ} \mathrm{C}$.

No significant correlations were found between summer SST $(0-50 \mathrm{~m})$ and shell diameter or porosity, neither for the Caribbean (Figure 10) nor for the Mediterranean morphotype (Figure 11). Also, no correlation was found between large pore- or small pore- density and paleo-SST.

\section{DISCUSSION}

\section{ORBULINA UNIVERSA MORPHOTYPES OCCURRENCE}

\section{AT THE Western South Atlantic}

Orbulina universa morphotypes are related to different hydrographic provinces and trophic conditions. Morard et al. (2009) relate the Mediterranean morphotype with high productivity regions, as the Southeast Atlantic and the Indian Ocean. On the other hand, Sargasso and Caribbean morphotypes seem to be specially related to stratified oligotrophic waters. In our
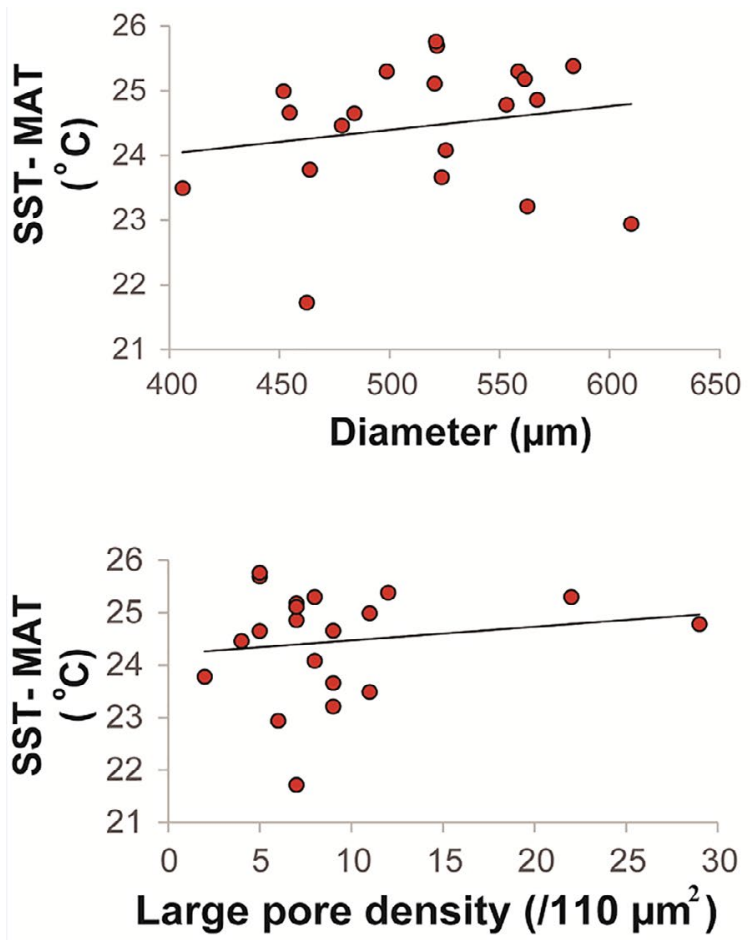

study, both Mediterranean and Caribbean morphotypes specimens occur together in almost all the samples (modern and fossil). Even though De Vargas et al. (1999) have reported the Sargasso morphotype occurrence at the Southwestern Atlantic, this morphotype was not considered for the studied samples. Morphometric characteristics of Mediterranean and Sargasso morphotypes are very similar, making it difficult to separate them. However, Sargasso morphotype occurrence is unlikely in our study area, once its higher abundance has been reported to highly oligotrophic regions of the ocean (De Vargas et al., 1999), such as the subtropical gyres (Morard et al., 2009).

The co-occurrence of Mediterranean and Caribbean morphotypes can be explained by the oceanographic characteristics of the area. The main oceanographic influence in the region comes from the Brazil Current (BC) (Piola and Matano, 2017) which transports warm and oligotrophic waters, enabling the occurrence of the Caribbean morphotype both in modern and fossil samples. On the other hand, there is also the influence of the PPW (that reaches the study area during winter under the influence of SW winds - Pimenta et al., 2005; Piola et al., 2005) and the coastal upwelling intensity at Santa Marta Cape (Acha et al., 2004; Pereira et al., 2009). Both bring colder
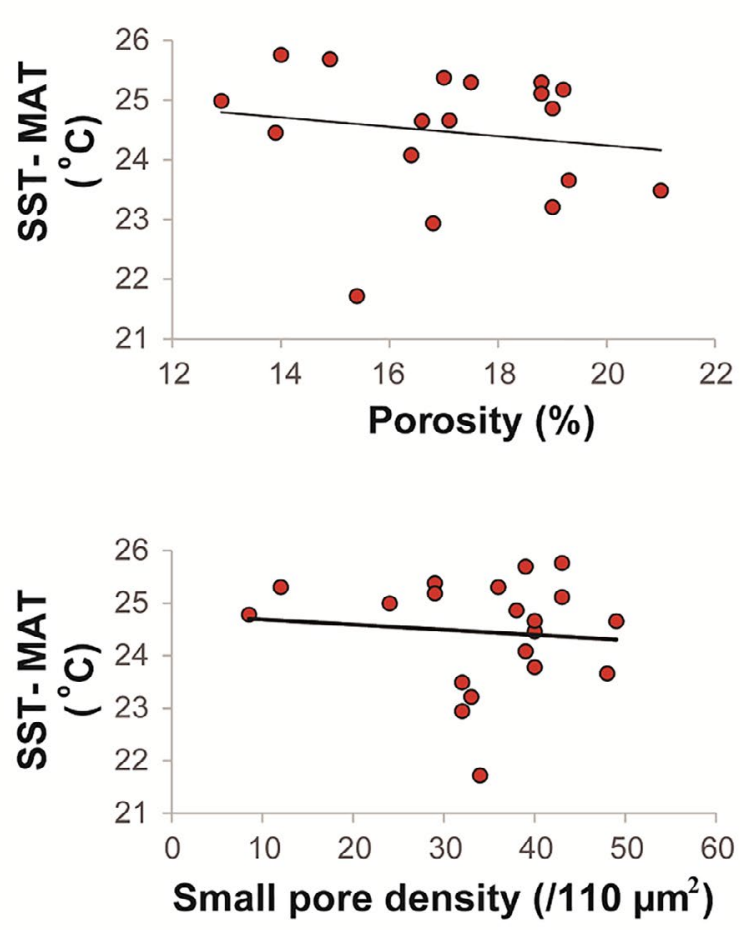

Figure 10. Relationships between SST $\left({ }^{\circ} \mathrm{C}\right)$ and the shell diameter, porosity and pore densities for the Caribbean morphotype in SIS188 core. 

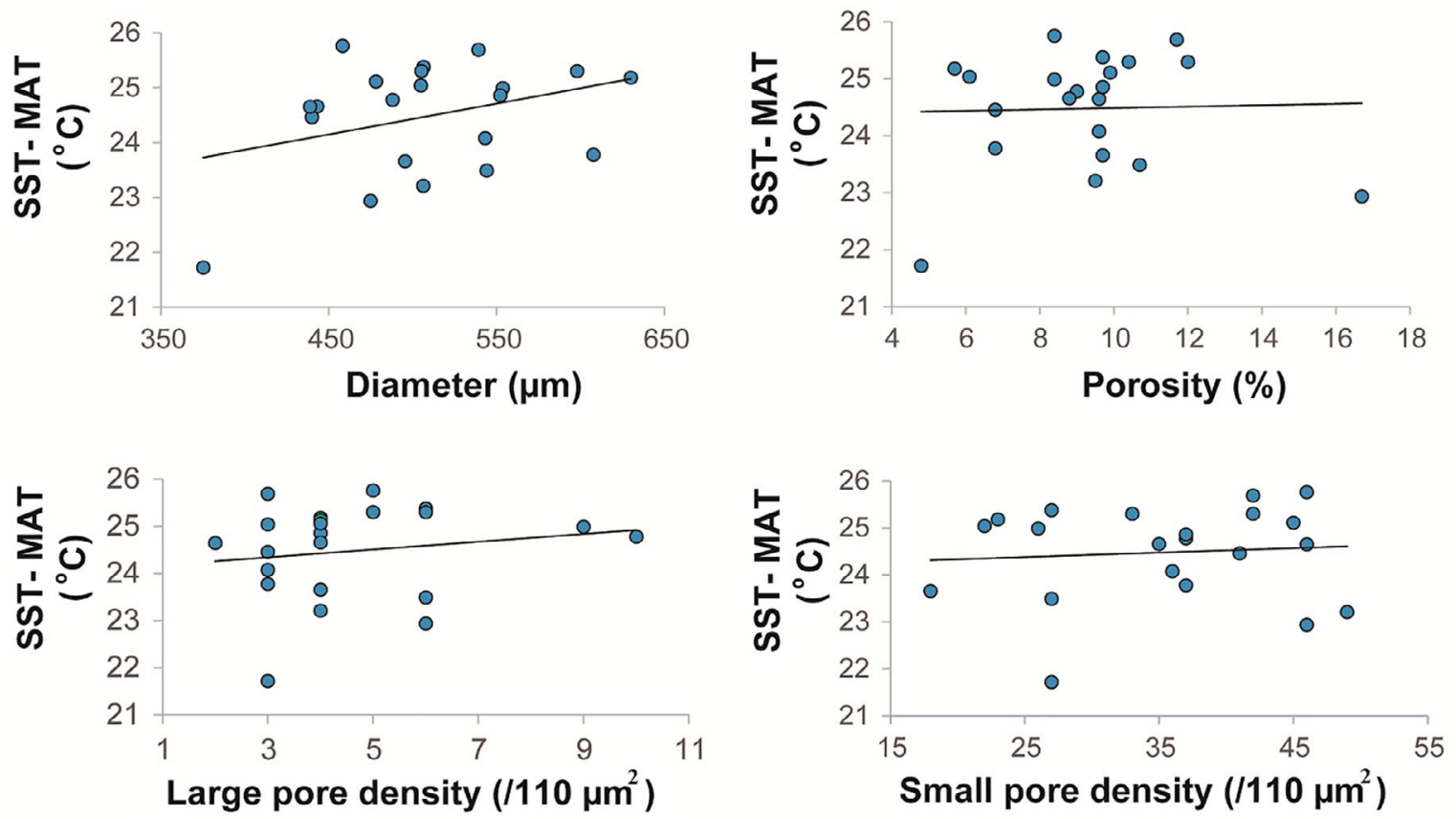

Figure 11. Relationships between SST $\left({ }^{\circ} \mathrm{C}\right)$ and the shell diameter, porosity and pore densities for the Mediterranean morphotype in SIS188 core.

and nutrient rich waters enabling the occurrence of the Mediterranean morphotype. Moreover, proxy data (i.e. Laprida et al., 2011; Voigt et al., 2015; Morard et al., 2016) provide evidence for shifts in the latitude of the $\mathrm{BMC}$ during the Pleistocene and Holocene. Under colder conditions, a northward migration of the Confluence region would have favored the occurrence of the Mediterranean morphotype in our fossil samples.

\section{Correlation BETWEEN ORBULINA UNIVERSA} MORPHOMETRIC PARAMETERS AND SURFACE WATERS

\section{THERMOHALINE INDEXES IN MODERN SAMPLES}

Large pore density is the only parameter that shows a significant correlation with temperature and salinity (Caribbean morphotype).

Previous studies have shown an association between pore density and porosity (which is affected by the pores density) and dissolved oxygen concentration and temperature. In fact, several studies relate higher porosity and shell diameter in O. universa and other planktonic foraminifera to warmer temperatures (Bé, 1968; Frerichs et al., 1972; Bé et al., 1973, in surface sediments; Li et al., 2009, in sedimentary cores; Lombard et al., 2009; Burke et al., 2018 , in laboratory cultures). Moreover, some studies have related higher pore density to a lower dissolved oxygen concentration (Schiebel and Hemleben, 2017). As gas dissolution in water is less efficient at higher temperatures, the number of pores in the shells increase to compensate the oxygen deficiency. The opposite situation occurs when the gas dissolution is higher, and the shells show lower porosities and less pores. Therefore, water temperature and oxygen concentration effects overlap. Nonetheless, in our samples the correlation found between pore density and water temperature is negative. It is possible that previous work results have been influenced by the fact that the existence of different morphotypes of $O$. universa was not considered. Still, lab studies conducted by Bijma et al. (1990) and Kuroyanagi et al. (2013) have found inverse correlations between temperature/dissolved oxygen concentration in water and porosity/pore density in shells, agreeing with our results. Thus, the mechanisms which define these shell morphometric parameters are still not quite understood.

Morard et al. (2009) show that the Caribbean morphotype presents higher porosity at subtropical warm waters, while the Mediterranean morphotype presents lower porosity in cold and high productivity waters in the Indian Ocean. Nonetheless, the authors did not establish a relationship between porosity and environmental conditions, but with genetic components. However, Morard et al. (2013) point to the temperature, together with productivity, as the most important parameters that influence the genotypes and morphotypes distribution. Nevertheless, the morphometric parameters related to the genotypes and its relationship with temperature are not addressed. 
Surprisingly, shell diameter did not show significant correlation with water temperature in our study area. This parameter has been commonly used in paleoceanographic studies, as at the North Atlantic, Indian Ocean and China Sea (Bé et al., 1973; Colombo and Cita, 1980; Schmidt et al., 2004; Li et al., 2009), showing a diameter increase together with a temperature increase. This may have happened because the morphometry changes do not depend only on temperature, but also on other factors, such as nutrient availability. Besides, shell diameter and water temperature do not exhibit a linear relation. Each species has a temperature range that leads to its maximum diameter, but environmental disturbances interfere in shell size. At frontal zones, as at the BMC, shell diameters use to be smaller (Schmidt et al., 2003).

\section{CORRELATION BETWEEN ORBULINA UNIVERSA} MORPHOMETRIC PARAMETERS AND SST IN SIS188 CORE

The fossil samples did not show any significant correlation between morphometric parameters and SST. This may have happened because carbonate fossil shells may have undergone dissolution processes. That would lead to an error of porosity estimate, as it takes into account the large and small pore diameters. However, porosity did not show significant correlation with thermohaline indexes in modern samples either. On the other hand, these processes would not affect pore density estimates, that show negative correlation with temperature for the modern samples, but not for the fossil samples.

There is also the possibility that other genotypes do exist in the fossil record and are yet not known (Morard et al., 2009). They could have temperature water preference different from the modern ones. If that is the case, individuals with the same morphometric characteristics would be classified as the same morphotype even if they have different environmental preferences, making it difficult to recognize a correlation between the two groups of variables. Unfortunately, studies considering the $O$. universa morphotypes have been made only for plankton samples.

Another explanation for the absence of correlation are errors associated with the SST estimates. The SST estimate was obtained by using the MAT. According to Guiot and De Vernal (2007), this technique has a confidence similar to other methods such as those based on Artificial Neural Networks, the $\mathrm{Mg} / \mathrm{Ca}$ ratios in planktonic foraminifera and the SIMMAX (with and without distance ponderation)
(Kucera et al., 2005a; Kucera et al., 2005b). However, MAT use can be limited by the small number of modern analogs found for the fossil samples set. This situation has been reported for the Southwest Pacific and the Southeast Atlantic (Morard et al., 2013) where there is a deterioration of SST reconstruction. In our work, several tests were made using the calibration dataset ForCenS2017 (Siccha and Kucera, 2017) for the South Atlantic. Nevertheless, SST estimates for the LGM and part of MIS 2 were too high and with abrupt changes for a short time period. Therefore, part of the Equatorial Atlantic was added to the calibration dataset, allowing the obtainment of a SST curve consistent with previous knowledge for the LGM at the Southwestern Atlantic (e.g.: Toledo et al., 2007a; Toledo et al., 2007b; Pivel et al., 2010). Another possible source of error in MAT reconstructions is related to the choice of the water depth temperature range considered in the calibration dataset (Telford et al., 2013). After testing three different depth ranges, we decided to use the $0-50 \mathrm{~m}$ range which was the one that yielded the best correlations between the modern and reconstructed temperatures. Still, we recognize that while recent fauna may better reflect present conditions at the $0-50 \mathrm{~m}$ depth range, past changes in the upper thermal structure very likely happened. Thus, intrinsic errors of the method could have diminished the correlation between SST and morphometric parameters.

Another hypothesis is that other factors, such as nutrient availability, play an important role in the morphotypes distribution. Currently, the main contributor to enhance nutrient availability at the area is the PPW. However, the modern sample closer to the La Plata river mouth $\left(35^{\circ} \mathrm{S}\right)$ was obtained at $32^{\circ} 55^{\prime} \mathrm{S}$. Furthermore, samples were collected in autumn and spring, while the extremes of PPW seasonal migration occur in summer (when it is restricted to the mouth proximity) and in winter (when it reaches its farther north position). Thus, it is possible that planktonic samples represent conditions in which temperature and salinity changes were more relevant that the nutrient availability fluctuations. On the other hand, during the last $32 \mathrm{kyr}$, nutrient availability changed significantly. During the LGM, with the lower global sea level and the modification of La Plata river mouth position, PPW influence was more intense, enhancing productivity of the affected area (Gu et al., 2017; Gu et al., 2018). In addition, the BMC, another high productivity area, has migrate to the north during Holocene (Voigt et al., 2015; Morard et al., 2016) possibly influencing the $O$. universa morphotypes distribution. Therefore, fossil samples could 
represent distinct and more complex oceanographic conditions compared to current configuration.

\section{CONCLUSION}

Two O. universa morphotypes were recognized in samples collected at the Southwestern Atlantic (Caribbean and Mediterranean morphotypes). Significant negative correlations were obtained between large pore density and temperature and salinity for the Caribbean morphotype in modern samples. For the Mediterranean morphotype, this correlation was only significant for temperature. None correlation was found between temperature and shells diameter, although it is a common proxy used in paleoceanographic researches. In fossil samples obtained in core SIS188 none correlation was observed, so their value as a source of paleoceanographic information should be seen with caution. Hypothesis to explain this apparent incongruence include errors in SST estimates using MAT, the existence of genotypes in the recent geological past that are distinct from the modern ones and the possible difference between the current oceanographic conditions and the paleoceanographic conditions during the last $32 \mathrm{kyr}$. Increasing the Southwest Atlantic dataset is central to understand the relationship between morphometric parameters of the $O$. universa morphotypes and the thermohaline indexes in modern and past conditions.

\section{ACKNOWLEDGEMENTS}

The authors are thankful to CAPES (Brazilian Coordination of Higher Education Staff Improvement) for the financial support (process 88887.091729/2014-01). They are also grateful to Dr Sandro M. Petró, Karlos G.D. Kochhann, Paula Dentizien Dias, José H. Muelbert and three anonymous reviewers for important suggestions and to Prof. Dr. Erik Muxagata and to the Zooplankton Laboratory of the Oceanography Institute of FURG for sharing the plankton samples that enabled part of this study.

We are also thankful to Pâmela Palhano for preparing samples for isotope analyses. Finally, the first author thanks the OAS (Organization of American States) and the CGBU (Coimbra Group of Brazilian Universities), for the master's scholarship that made possible the development of this research project

\section{REFERENCES}

ACHA, E. M., MIANZAN, H. W., GUERRERO, R. A., FAVERO, M. \& BAVA, J. 2004. Marine fronts at the continental shelves of austral South America. Journal of Marine Systems, 44, 83-105.
ALVES, E., MACARIO, K., SOUZA, R., PIMENTA, A., DOUKA, K., OLIVEIRA, F., CHANCA, I. \& ANGULO, R. 2015. Radiocarbon reservoir corrections on the Brazilian coast from pre-bomb marine shells. Quaternary Geochronology, 29, 30-35.

ANGUlO, R. J., DE SOUZA, M. C., REIMER, P. J. \& SASAOKA, S. K. 2005. Reservoir Effect of the Southern and Southeastern Brazilian Coast. Radiocarbon, 47, 67-73.

BÉ, A.W. H. \& DUPLESSY, J. C. 1976. Subtropical Convergence Fluctuations and Quaternary Climates in the Middle Latitudes of the Indian Ocean. Science, 194, 419-422.

BÉ, A. W. H. 1968. Shell Porosity of Recent planktonic foraminifera as a climatic index. Science, 161, 881-884

BÉ, A. W. H., HARRISON, S. M. \& LOTT, L. 1973. Orbulina universa d'Orbigny in the lndian Ocean. Micropaleontology, $19,150-192$

BÉ, A. W. H., HEMLEBEN, C., ANDERSON, O. R. \& SPINDLER, M. 1980. Pore structures in planktonic foraminifera. The Journal of Foraminiferal Research, 10, 117-128.

BIJMA, J., FABER, W. W. \& HEMLEBEN, C. 1990. Temperature and salinity limits for growth and survival of some planktonic foraminifers in laboratory cultures. The Journal of Foraminiferal Research, 20, 95-116.

BOUDAGHER-FADEL, M. K. 2012. An introduction to planktonic foraminifera. Developments in Palaeontology and Stratigraphy, 22, 1-32.

BURKE, J. E., RENEMA, W., HENEHAN, M. J., ELDER, L. E., DAVIS, C. V., MAAS, A. E., FOSTER, G. L., SCHIEBEL, R. \& HULL, P. M. 2018. Factors influencing test porosity in planktonic foraminifera. Biogeosciences, 15, 6607-6619.

CAMPOS, P. C., MÖLLER JR, O. O., PIOLA, A. R. \& PALMA, E. D. 2013. Seasonal variability and coastal upwelling near Cape Santa Marta (Brazil). Journal of Geophysical Research: Oceans, 118, 1420-1433.

CASTELAO, R. M. \& BARTH, J. A. 2006. Upwelling around Cabo Frio, Brazil: The importance of wind stress curl. Geophysical Research Letters, 33, 2-5.

CLIMAP PROJECT MEMBERS. 1976. The Surface of the Ice-Age Earth. Science, 191, 1131-1137.

COLOMBO, M. R. \& CITA, M. B. 1980. Changes in size and test porosity of Orbulina universa d'Orbigny in the Pleistocene record of Cape Bojador (DSDP Site 397, eastern North Atlantic). Marine Micropaleontology, 5, 13-29.

DE MASI, M. A. N. 1999. Prehistoric hunter-gatherer mobility on the southern Brazilian coast: Santa Catarina Island. Stanford, Stanford University.

DE VARGAS, C., NORRIS, R., ZANINETTI, L., GIBB, S. W. \& PAWLOWSKI, J. 1999. Molecular evidence of cryptic speciation in planktonic foraminifers and their relation to oceanic provinces. Proceedings of the National Academy of Sciences of the United States of America, 96, 2864-2868.

EMILIANI, C. 1954. Depth habitats of some species of pelagic Foraminifera as indicated by oxygen isotope ratios. American Journal of Science, 252, 149-158.

FRERICHS, W. E., HEIMAN, M. E., BORGMAN, L. E. \& BÉ, A. W. H. 1972. Latitudal variations in planktonic foraminiferal test porosity; Part 1, Optical studies. Journal of Foraminiferal Research, 2, 6-13.

GU, F., ZONNEVELD, K. A. F., CHIESSI, C. M., ARZ, H. W., PÄTZOLD, J. \& BEHLING, H. 2017. Long-term vegetation, climate and ocean dynamics inferred from a 73,500 years old marine sediment core (GeoB2107-3) off southern Brazil. Quaternary Science Reviews, 172, 55-71. 
GU, F., CHIESSI, C. M., ZONNEVELD, K. A. F. \& BEHLING, H. 2018. Late Quaternary environmental dynamics inferred from marine sediment core GeoB6211-2 off southern Brazil. Palaeogeography, Palaeoclimatology, Palaeoecology, 496, 48-61.

GUIOT, J. \& DE VERNAL, A. 2007. Chapter Thirteen Transfer Functions: Methods for Quantitative Paleoceanography Based on Microfossils. Developments in Marine Geology, 1, 523-563.

HECHT, A., BÉ, A. W. H. \& LOTT, L. 1976. Ecologic and Paleoclimatic Implications of Morphologic Variation of Orbulina universa in the Indian Ocean. Science, 194, 422-424.

HEMLEBEN, C., SPINDLER, M. \& ANDERSON, O. 1989. Modern Planktonic Foraminifera, New York, Springer-Verlag.

HUTSON, W. H. 1980. The Agulhas Current During the Late Pleistocene: Analysis of Modern Faunal Analogs. Science, 4426, 64-66.

IMBRIE, J. \& KIPP, N. 1971. A new micropaleontological method for quantitative paleoclimatology: Application to a Late Pleistocene Caribbean core. In: FLINT, R. F. (ed.) The Late Cenozoic Glacial Ages. New Haven: Yale University Press.

KUCERA, M., WEINELT, M., KIEFER, T., PFLAUMANN, U., HAYES, A., WEINELT, M., CHEN, M. T., MIX, A. C., BARROWS, T. T., CORTIJO, E., DUPRAT, J., JUGGINS, S. \& WAELBROECK, C. 2005a. Reconstruction of sea-surface temperatures from assemblages of planktonic foraminifera: multi-technique approach based on geographically constrained calibration data sets and its application to glacial Atlantic and Pacific Oceans. Quaternary Science Reviews, 24, 951-998.

KUCERA, M., ROSELL-MELÉ, A., SCHNEIDER, R., WAELBROECK, C. \& WEINELT, M. 2005b. Multiproxy approach for the reconstruction of the glacial ocean surface (MARGO). Quaternary Science Reviews, 24, 813-819.

KUROYANAGI, A., DA ROCHA, R. E., BIJMA, J., SPERO, H. J., RUSSELL, A. D., EGGINS, S. M. \& KAWAHATA, H. 2013. Effect of dissolved oxygen concentration on planktonic foraminifera through laboratory culture experiments and implications for oceanic anoxic events. Marine Micropaleontology, 101, 28-32.

LAPRIDA, C., CHAPORI, N. G., CHIESSI, C. M., VIOLANTE, R. A., WATANABE, S. \& TOTAH, V. 2011. Middle Pleistocene sea surface temperature in the Brazil-Malvinas Confluence Zone: Paleoceanographic implications based on planktonic foraminifera. Micropaleontology, 57, 183-195.

LEA, D. W., MARTIN, P. A., PAK, D. K. \& SPERO, H. J. 2002. Reconstructing a 350ky history of sea level using planktonic $\mathrm{Mg} / \mathrm{Ca}$ and oxygen isotope records from a Cocos Ridge core. Quaternary Science Reviews, 21, 283-293.

LI, B. H., WANG, X. Y., JIAN, Z. M. \& WANG, P. X. 2009. Sea surface environment inferred from planktonic foraminifera in the southern South China Sea since the last glacial period. Palaeoworld, $18,23-33$.

LISIECKI, L. E. \& STERN, J. V. 2016. Regional and global benthic $\delta 18 \mathrm{O}$ stacks for the last glacial cycle, Paleoceanography, 31, 1368-1394.

LOCARNINI, R. A., MISHONOV A.V. J. I., ANTONOV, T. P., BOYER, H. E., GARCIA, O. K., BARANOVA, M. M., ZWENG, C. R., PAVER, J. R., REAGAN, D. R., JOHNSON, M. \& HAMILTON, D. S. 2013. World Ocean Atlas 2013, Volume 1: Temperature. In: LEVITUS, A., MISHONOV, S. (eds.). NOAA Atlas NESDIS. Silver Spring: NOAA.

LOMBARD, F., LABEYRIE, L., MICHEL, E., SPERO, H. J. \& LEA, D. W. 2009. Modelling the temperature dependent growth rates of planktic foraminifera. Marine Micropaleontology, 70, 1-7.
LOURENS, L., HILGEN, F., SHACKLETON, N. J., LASKAR, J. \& WILSON, D. 2004. The Neogene Period. In: GRANDSTEIN, F. M., F. M. OGG, J. G. \& SMITH, A. G. (eds). A Geologic Time Scale 2004. Cambridge: Cambridge University Press.

MARSHALL, B. J., THUNELL, R. C., SPERO, H. J., HENEHAN, M. J., LORENZONI, L. \& ASTOR, Y. 2015. Morphometric and stable isotopic differentiation of Orbulina universa morphotypes from the Cariaco Basin, Venezuela. Marine Micropaleontology, 120, 46-64.

MORARD, R., QUILLÉVÉRÉ, F., ESCARGUEL, G., UJIIE, Y., DE GARIDEL-THORON, T., NORRIS, R. D. \& DE VARGAS, C. 2009. Morphological recognition of cryptic species in the planktonic foraminifer Orbulina universa. Marine Micropaleontology, 71, 148-165.

MORARD, R., QUILLÉVÉRÉ, F., ESCARGUEL, G., DE GARIDEL-THORON, T., DE VARGAS, C. \& KUCERA, M. 2013. Ecological modeling of the temperature dependence of cryptic species of planktonic Foraminifera in the Southern Hemisphere. Palaeogeography, Palaeoclimatology, Palaeoecology, 391, 13-33.

MORARD, R., REINELT, M., CHIESSI, C. M., GROENEVELD, J. \& KUCERA, M. 2016. Tracing shifts of oceanic fronts using the cryptic diversity of the planktonic foraminifera Globorotalia inflata. Paleoceanography, 31, 1193-1205.

PAILLARD, D., LABEYRIE, L. \& YIOU, P. 1996. Macintosh program performs time-series analysis. EOS, Transactions American Geophysical Union, 77, 379.

PALMA, E. D. \& MATANO, R. P. 2009. Disentangling the upwelling mechanisms of the South Brazil Bight. Continental Shelf Research, 29, 1525-1534.

PEREIRA, M. D., SCHETTINI, C. A. F. \& OMACHI, C. Y. 2009. Caracterização de feições oceanográficas na plataforma de Santa Catarina através de imagens orbitais. Revista Brasileira de Geofisica, 27, 81-93.

PETERSON, R. G. \& STRAMMA, L. 1991. Upper-level circulation in the South Atlantic Ocean. Progress in Oceanography, 26, 1-73.

PILLAR, V. 2006. MULTIV:Multivariate exploratory analysis, randomization testing and bootstrap resampling. Department of Ecology, Universidade Federal do Rio Grande do Sul, Porto Alegre, Brazil.

PIMENTA, F. M., CAMPOS, E. J. D., MILLER, J. L. \& PIOLA, A. R. 2005. A numerical study of the Plata River plume along the southeastern South American continental shelf. Brazilian Journal of Oceanography, 53, 129-146.

PIOLA, A. R., MATANO, R. P., PALMA, E. D., MÖLLER JR, O. O. \& CAMPOS, E. J. 2005. The influence of the Plata River discharge on the western South Atlantic shelf. Geophysical Research Letters, 32, 1-4.

PIOLA, A. R. \& MATANO, R. P. 2017. Ocean Currents: Atlantic Western Boundary- Brazil Current/Falkland (Malvinas) Current. Earth Systems and Environmental Sciences, 1-7.

PIVEL, M. A., TOLEDO, F. \& COSTA, K. 2010. Foraminiferal record of changes in summer monsoon precipitation at the southeastern Brazilian continental margin since the Last Glacial Maximum. Revista Brasileira de Paleontologia, 13, 79-88.

REIMER, P. J., BARD, E., BAYLISS, A., BECK, J. W., BLACKWELL, P. G., RAMSEY, C. B., BUCK, C. E., CHENG, H., EDWARDS, R. L., FRIEDRICH, M., GROOTES, P. M., GUILDERSON, T. P., HAFLIDASON, H., HAJDAS, I., HATTÉ, C., HEATON, T. J., HOFFMANN, D. L., HOGG, A. G., HUGHEN, K. A., KAISER, K. F., KROMER, B., MANNING, S. W., NIU, M., REIMER, R. W., RICHARDS, D. A., SCOTT, E. M., SOUTHON, J. R., STAFF, R. A., TURNEY, C. S. M. \& VAN DER PLICHT, J. 2013. IntCal13 and Marine13 Radiocarbon Age Calibration Curves 0-50,000 Years cal BP. Radiocarbon, 55, 1869-1887. 
SCHIEBEL, R. \& HEMLEBEN, C. 2017. Planktic Foraminifers in the Modern Oceans. Berlin Heidelberg, Springer-Verlag.

SCHMIDT, D. N., RENAUD, S. \& BOLLMANN, J. 2003. Response of planktic foraminiferal size to late Quaternary climate change. Paleoceanography, 18, 1-12.

SCHMIDT, D. N., RENAUD, S., BOLLMANN, J., SCHIEBEL, R. \& THIERSTEIN, H. R. 2004. Size distribution of Holocene planktic foraminifer assemblages: biogeography, ecology and adaptation. Marine Micropaleontology, 50, 319-338.

SEEARS, H. 2011. Biogeography and Phylogenetics of the Planktonic Foraminifera. Nottingham, University of Nottingham.

SICCHA, M. \& KUCERA, M. 2017. ForCenS, a curated database of planktonic foraminifera census counts in marine surface sediment samples. Scientific Data, 4, 1-12.

SILVEIRA, I. C. A., SCHMIDT, A. C. K., CAMPOS, E. J. D., GODOI, S. S. \& IKEDA, Y. 2000. A corrente do Brasil ao largo da costa leste brasileira. Revista Brasileira de Oceanografia, 48, 171183.
SOUZA, R. B. \& ROBINSON, I. S. 2004. Lagrangian and satellite observations of the Brazilian Coastal Current. Continental Shelf Research, 24, 241-262.

SPERO, H. J. 1988. Ultrastructural examination of chamber morphogenesis and biomineralization in the planktonic foraminifer $\mathrm{Orbu}$ lina universa. Marine Biology, 99, 9-20.

TELFORD, R. J., LI, C. \& KUCERA, M. 2013. Mismatch between the depth habitat of planktonic foraminifera and the calibration depth of SST transfer functions may bias reconstructions. Climate of the Past, 9, 859-870.

TOLEDO, F. A. L., COSTA, K. B. \& PIVEL, M. A. G. 2007a. Salinity changes in the western tropical South Atlantic during the last 30 kyr. Global and Planetary Change, 57, 383-395.

TOLEDO, F. A. L., CACHÃO, M., COSTA, K. B. \& PIVEL, M. A. G. 2007b. Planktonic foraminifera, calcareous nannoplankton and ascidian variations during the last $25 \mathrm{kyr}$ in the Southwestern Atlantic: A paleoproductivity signature?. Marine Micropaleonto$\log y, 64,67-79$.

VOIGT, I., CHIESSI, C. M., PRANGE, M., MULITZA, S., GROENEVELD, J., VARMA, V. \& HENRICH, R. 2015. Holocene shifts of the southern westerlies across the South Atlantic. Paleoceanography, 30, 39-51. 